\title{
Removal of lead from aqueous solutions by electrocoagulation: isotherm, kinetics and thermodynamic studies
}

\author{
R. Kamaraj • P. Ganesan · S. Vasudevan
}

Received: 7 September 2012/Revised: 27 August 2013/Accepted: 24 November 2013/Published online: 10 December 2013

(C) Islamic Azad University (IAU) 2013

\begin{abstract}
The present study provides an electrocoagulation process for the removal of lead from water using magnesium and galvanized iron as anode and cathode, respectively. The various operating parameters such as the effect of initial $\mathrm{pH}$, current density, electrode configuration, inter-electrode distance, co-existing ions and temperature on the removal efficiency of lead were studied. The results showed that the maximum removal efficiency of $99.3 \%$ at a $\mathrm{pH}$ of 7.0 was achieved at a current density $0.8 \mathrm{~A} / \mathrm{dm}^{2}$ with an energy consumption of $0.72 \mathrm{kWh} / \mathrm{m}^{3}$. The experimental data were fitted with several adsorption isotherm models to describe the electrocoagulation process. The adsorption of lead preferably fitting the Langmuir adsorption isotherm suggests monolayer coverage of adsorbed molecules. In addition, the adsorption kinetic studies showed that the electrocoagulation process was best described using the second-order kinetic model at various current densities. Thermodynamic parameters, including the Gibbs free energy, enthalpy and entropy, indicated that the lead adsorption of water on magnesium hydroxides was feasible, spontaneous and endothermic.
\end{abstract}

Keywords Electrocoagulation · Heavy metal · Adsorption $\cdot$ Kinetics $\cdot$ Thermodynamics

Electronic supplementary material The online version of this article (doi:10.1007/s13762-013-0457-z) contains supplementary material, which is available to authorized users.

R. Kamaraj · P. Ganesan · S. Vasudevan $(\bowtie)$

CSIR, Central Electrochemical Research Institute,

Karaikudi 630 006, India

e-mail: vasudevan65@gmail.com

\section{Introduction}

Heavy metal pollution is an important environmental problem in the aqueous system originated from different sources. Mainly this heavy metal pollution exists in many industrial wastewaters, such as mining operations, metal finishing and production industries such as fertilizer, paints, pigments, battery, tannery, household plumbing materials, water service lines, atomic energy installation, leatherworking, photography and salvages yards (Argun et al. 2007; Sing et al. 2006; Heil et al. 1999). Various metals associated with these activities are lead, cadmium, mercury, copper, chromium, etc. Heavy metals are not biodegradable and tend to accumulate into living organisms, causing various diseases and other problems. This heavy metal is also known carcinogen. Lead is an enzyme inhibitor, and human intake of lead causes disruption of the biosynthesis of hemoglobin, rise in blood pressure, kidney damage, miscarriages and abortions, brain damage and diminished learning abilities of children. According to the WHO, the maximum permissible limit (MPL) of lead in drinking water is $0.05 \mathrm{mg} / \mathrm{L}$ (WHO 2009). Hence, proper treatment of industrial wastewaters that are releasing lead into the aquatic and land systems is very important.

The common methods for removing lead from water includes chemical precipitation (Matlock et al. 2001), ion exchange (Inglezakis et al. 2007), membrane separation, flotation, biosorption (Nurbas Nourbakhsh et al. 2002; Gupta and Ali 2004) and adsorption (Mohan and Chander 2006; Gupta and Sharma 2002). At present, chemical treatments are not used due to disadvantages such as high costs of maintenance, problems of sludge handling and its disposal, and neutralization of effluent.

Recent research has demonstrated that electrocoagulation offers an attractive alternative to aforementioned 
traditional methods for treating water (Kabdasl et al. 2012). In this process, anodic dissolution of metal electrode takes place with the evolution of hydrogen gas at the cathode (Vasudevan et al. 2010). Electrochemically generated metallic ions from the anode can undergo hydrolysis to produce a series of activated intermediates that are able to destabilize the finely dispersed particles present in the water to be treated. The destabilized particles then aggregate to form flocks as outlined below. The advantages of electrocoagulation include high particulate removal efficiency, a compact treatment facility, relatively low cost and the possibility of complete automation. This method is characterized by reduced sludge production, a minimum requirement of chemicals and ease of operation (Butler et al. 2011).

Besides, the main disadvantage in case of aluminum electrode is the residual aluminum (the WHO guidelines suggest maximum contamination is $0.05-0.2 \mathrm{mg} / \mathrm{L}$ ) present in the treated water due to anodic dissolution. This will lead to health problems such as cancer. There is no such health problem in the case of magnesium electrode, because the WHO guidelines suggest that the maximum contamination level of magnesium in water is $30 \mathrm{mg} / \mathrm{L}$. Although there are numerous reports dealt with electrocoagulation as a means of removal of many pollutants from water and wastewater, there are few studies on the removal of lead by electrocoagulation method.

This article presents the results of the laboratory-scale studies on the removal of lead using magnesium and stainless steel as anode and cathode, respectively, by electrocoagulation process. To optimize the maximum removal efficiency of lead, different reaction conditions such as the effect of current density, co-existing ions, effect of temperature and $\mathrm{pH}$ were studied. In doing so, the equilibrium adsorption behavior is analyzed by fitting the isotherm models of Langmuir and Freundlich. Adsorption kinetics of electrocoagulants is analyzed using first- and second-order kinetic models. Activation energy was evaluated to study the nature of adsorption. This work was carried out in Electroinorganic Division, CSIR-Central Electrochemical Research Institute, Karaikudi, Tamil Nadu, India, during January to July 2011.

\section{Materials and methods}

Experimental apparatus and procedures

The electrolytic cell consisted of a 1-L plexiglas vessel that was fitted with a poly-(vinyl chloride) cell cover with slots to introduce the electrodes, $\mathrm{pH}$ sensor, a thermometer and the electrolytes. The anode and cathode with surface area of $0.2 \mathrm{dm}^{2}$ were made of magnesium sheet (Alfa Aesar, UK) and stainless steel (commercial grade) and are placed at an inter-electrode distance of $5 \mathrm{~mm}$. The temperature of the electrolyte was controlled to the desired value with a variation of $\pm 2 \mathrm{~K}$ by adjusting the rate of flow of thermostatically controlled water through an external glasscooling spiral. A regulated direct current (DC) was supplied from a rectifier (10 A, 0-25 V; Aplab model).

Lead nitrate $\mathrm{Pb}\left(\mathrm{NO}_{3}\right)_{2}$ (Merck, Darmstadt, Germany) was dissolved in distilled water for the required concentration. The solution of $0.90 \mathrm{~L}$ was used for each experiment as the electrolyte. The $\mathrm{pH}$ of the electrolyte was adjusted, if required, with $\mathrm{HCl}$ or $\mathrm{NaOH}$ (Merck, Darmstadt, Germany) solutions before adsorption experiments. To study the effect of co-existing ions in the removal of lead, sodium salts (Analar Grade) of phosphate $(5-50 \mathrm{mg} / \mathrm{L})$, silicate $(5-15 \mathrm{mg} / \mathrm{L})$, carbonate $(5-250 \mathrm{mg} / \mathrm{L})$ and arsenic $(0.2-5 \mathrm{mg} / \mathrm{L})$ were added to the electrolyte. Temperature studies were carried out at varying temperature (313-343 K) to determine the type of reaction.

\section{Analytical techniques}

The concentration of lead was determined using UV-visible Spectrophotometer (MERCK, Pharo 300, Germany) using standard MERCK kit. EDAX of magnesium hydroxide was analyzed with a scanning electron microscope (SEM) made by Hitachi (model s-3,000 h). The Fourier transform infrared spectrum of magnesium hydroxide was obtained using Nexus 670 FTIR spectrometer (Thermo Electron Corporation, USA). Magnesium hydroxide coagulant was analyzed by X-ray diffraction (XRD) made by JEOL (Type-JEOL, Japan). The concentration of carbonate, silicate, arsenic and phosphate was determined using UV-visible spectrophotometer (MERCK, Pharo 300).

\section{Theory}

\section{Adsorption kinetic modeling}

In order to investigate the mechanisms of the adsorption process, two different kinetic models, the first- and secondorder Lagergren models, were applied to describe the kinetics of the lead adsorption onto magnesium hydroxides (Sing et al. 2006). 


\section{First-order Lagergren model}

The first-order Lagergren model is one of the most widely used expressions describing the adsorption of solute from a solution (Sing et al. 2006). The first-order Lagergren model is generally expressed as follows:

$\mathrm{d} q_{t} / \mathrm{d} t=k_{1}\left(q_{e}-q_{t}\right)$

where $q_{e}(\mathrm{mg} / \mathrm{g})$ and $q_{t}(\mathrm{mg} / \mathrm{g})$ are the amounts of lead adsorbed on the adsorbent at equilibrium and at any time $t$ (min), respectively, and $k_{1}\left(\mathrm{~min}^{-1}\right)$ is the rate constant of the first-order model. The integrated form of the above equation with the boundary conditions $t=0$ to $>0$ ( $q=0$ to $>0$ ) is rearranged to obtain the following timedependence function,

$\log \left(q_{e}-q_{t}\right)=\log \left(q_{e}\right)-k_{1} t / 2.303$

The first-order model considers the rate of occupation of the adsorption sites proportional to the number of unoccupied sites.

\section{Second-order Lagergren model}

The Lagergren second-order kinetic model is expressed as (Mckay and Ys 1999)

$\mathrm{d} q_{t} / \mathrm{d} t=k_{2}\left(q_{e}-q_{t}\right)^{2}$

where $k_{2}$ is the rate constant of second-order adsorption. The integrated form of Eq. (3) with the boundary condition $t=0$ to $>0(q=0$ to $>0)$ is as follows:

$1 /\left(q_{e}-q_{t}\right)=1 / q_{e}+k_{2} t$

Equation (4) can be rearranged and linearized as,

$t / q_{t}=1 / k_{2} q_{e}^{2}+t / q_{e}$

where $q_{e}$ and $q_{t}$ are the amount of lead adsorbed on $\mathrm{Mg}(\mathrm{OH})_{2}$ ( $\left.\mathrm{mg} / \mathrm{g}\right)$ at equilibrium and at time $t$ ( $\left.\mathrm{min}\right)$, respectively, and $k_{2}$ is the rate constant for the second-order kinetic model.

\section{Adsorption isotherms modeling}

To investigate the adsorption capacity of lead on $\mathrm{Mg}(\mathrm{OH})_{2}$, Freundlich (1906) and Langmuir (1918) isotherms were analyzed. These models have been widely used to describe the behavior of adsorbent-adsorbate systems. To obtain the isotherms, the initial $\mathrm{pH}$ was kept at 7 and the current density was in the range of $0.2-0.8 \mathrm{~A} / \mathrm{dm}^{2}$.

\section{Freundlich isotherm}

The Freundlich adsorption isotherm model includes considerations of surface heterogeneity and exponential distribution of the active sites and their energies. The isotherm is adopted to describe reversible adsorption and is not restricted to monolayer formation. This isotherm typically fits the experimental data over a wide range of concentrations. The linearized and logarithmic expression of the Freundlich (1906) model is

$\log q_{e}=\log k_{f}+n \log C_{e}$

where $k_{f}(\mathrm{mg} / \mathrm{g})$ and $\mathrm{n}$ (dimensionless) are constants that account for all factors affecting the adsorption process, such as the adsorption capacity and intensity. The Freundlich constants $k_{f}$ and $\mathrm{n}$ are determined from the intercept and slope, respectively, of the linear plot of $\log q_{e}$ versus $\log C_{e}$.

\section{Langmuir isotherm}

The Langmuir isotherm model was developed to represent chemisorptions at a set of well-defined localized adsorption sites with the same adsorption energy, independent of the surface coverage, and with no interaction between adsorbed molecules. This model assumes a monolayer deposition on a surface with a finite number of identical sites. The linearized form of Langmuir adsorption isotherm model is (Langmuir 1918),

$C_{e} / q_{e}=1 / q_{m} b+C_{e} / q_{m}$

where $q_{e}(\mathrm{mg} / \mathrm{g})$ is amount adsorbed at equilibrium, $C_{e}$ $(\mathrm{mg} / \mathrm{L})$ equilibrium concentration, $q_{m}$ is the Langmuir constant representing maximum monolayer adsorption capacity, and $b$ is the Langmuir constant related to energy of adsorption.

The essential characteristics of the Langmuir isotherm can be expressed as the dimensionless constant $R_{L}$ (Oguz 2004).

$R_{L}=1 /\left(1+b C_{o}\right)$

where $R_{L}$ is the equilibrium constant and indicates the type of adsorption, $b$ is the Langmuir constant. $C_{\mathrm{o}}$ is various concentration of lead solution. The $R_{L}$ values between 0 and 1 indicate the favorable adsorption.

\section{Effect of temperature on thermodynamic adsorption} parameters

To understand the effect of temperature on adsorption process, thermodynamic parameters should be determined 
at various temperatures. The energy of activation for adsorption of lead can be determined by the second-order rate constant and it is expressed in Arrhenius form (Yang and Al-Duri 2001)

$\log k_{2}=\log \quad k_{\mathrm{o}}-2.303 E / R T$

where $k_{\mathrm{o}}$ is the constant of the equation $(\mathrm{g} / \mathrm{mg} \mathrm{min}), E$ is the energy of activation $(\mathrm{J} / \mathrm{mol}), R$ is the gas constant $(8.314 \mathrm{~J} / \mathrm{molK})$, and $T$ is the temperature in $\mathrm{K}$. The free energy change is obtained using the following relationship

$\Delta G=-R T \ln K_{\mathrm{c}}$

where $\Delta G$ is the free energy $(\mathrm{kJ} / \mathrm{mol}), K_{\mathrm{c}}$ is the equilibrium constant, $R$ is the universal gas constant, and $T$ is the temperature in $\mathrm{K}$. The relationship between $\Delta G, \Delta H$ and $\Delta S$ can be expressed by the following equation:

$\Delta G=\Delta H-T \Delta S$

Combining Eqs. 10 and 11 leads to

$\ln K_{c}=\frac{\Delta S}{R}-\frac{\Delta H}{R T}$

Enhancement of adsorption capacity of electrocoagulant (magnesium hydroxide) at higher temperatures may be attributed to the enlargement of pore size and/or activation of the adsorbent surface.

\section{Results and discussion}

\section{Effect of inter-electrode distance}

To determine the effect of various inter-electrode distances between anode and cathode, the electrodes were kept at different spacing of 0.003, 0.005, 0.007, 0.009 and $0.011 \mathrm{~m}$ using solutions containing $2 \mathrm{mg} / \mathrm{L}$ of lead at a current density of $0.8 \mathrm{~A} / \mathrm{dm}^{2}$. The results of inter-electrode distance on removal efficiency and energy consumption are presented in Figure S1 (a\&b). Decrease in energy consumption and increase in removal efficiency were observed while decreasing the inter-electrode distance. Short distance between anodes and cathodes requires low electrical energy for motion of ions. This is due to shorter travel path that reduce the resistance of motion of ions, and the situation is reverse in the case of large distance between each electrode. Maintaining the inter-electrode distance of $0.003 \mathrm{~m}$ was practically difficult. So, further experiments were carried out at interelectrode distance of $0.005 \mathrm{~m}$. Inter-electrode spacing of $0.005 \mathrm{~m}$ had the low energy consumption and high removal efficiency.
Effect of electrolyte $\mathrm{pH}$

As it has been proved, $\mathrm{pH}$ has an important effect on electrocoagulation process. To explain this effect, a series of experiments were carried out using solutions containing $2 \mathrm{mg} / \mathrm{L}$ of lead, by adjusting the initial $\mathrm{pH}$ from 3 to 11. The removal efficiency of lead was increased with increasing the $\mathrm{pH}$ up to 7 and decreased gradually above 7 . It is found that the maximum removal efficiency for the removal of lead is $99.3 \%$ at $\mathrm{pH} 7$ and the minimum efficiency is $82.7 \%$ at $\mathrm{pH} 3$. At acidic and alkaline $\mathrm{pHs}$, the oxide surfaces exhibit net positive and negative charges, respectively, and would tend to repulse the adsorption of lead, resulting the maximum adsorption at $\mathrm{pH}$ 7.0.

Effect of electrode configurations

The effect of electrode configuration (monopolar and bipolar) for the removal of lead was analyzed with various current densities from 0.2 to $0.8 \mathrm{~A} / \mathrm{dm}^{2}$ at a concentration of $2 \mathrm{mg} / \mathrm{L}$. The results are given in Table 1. From Table 1, it was observed that for given current densities, the removal efficiencies were almost equal for bipolar and monopolar electrode configurations. But the energy consumption was higher in the case of monopolar configuration rather than the bipolar configuration which is due to higher voltage in the case of former one.

\section{Effect of applied current}

Applied current, in other words current density, is the most important parameter for controlling the reaction rate within the electrochemical reactor in all electrochemical processes. In the case of electrocoagulation, current density determines the coagulant rate and the bubble production rate in the electrochemical cell (Mohammad et al. 2004). To investigate the effect of current

Table 1 Effect of electrode configuration on removal efficiency of lead at various current densities with lead concentration of $2 \mathrm{mg} / \mathrm{L}$

\begin{tabular}{llllll}
\hline $\begin{array}{l}\text { Current } \\
\text { density } \\
\left(\mathrm{A} / \mathrm{dm}^{2}\right)\end{array}$ & \begin{tabular}{l} 
Monopolar electrodes \\
\cline { 5 - 6 }
\end{tabular} & $\begin{array}{l}\text { Removal } \\
\text { efficiency } \\
(\%)\end{array}$ & $\begin{array}{l}\text { Energy } \\
\text { consumption } \\
(\mathrm{kWh} / \mathrm{kL})\end{array}$ & $\begin{array}{l}\text { Removal } \\
\text { efficiency } \\
(\%)\end{array}$ & $\begin{array}{l}\text { Energy } \\
\text { consumption } \\
(\mathrm{kWh} / \mathrm{kL})\end{array}$ \\
\hline 0.2 & 96.90 & 0.0181 & 97.05 & 0.0155 \\
0.4 & 97.05 & 0.1270 & 97.25 & 0.1230 \\
0.6 & 97.45 & 0.3628 & 97.91 & 0.3547 \\
0.8 & 99.30 & 0.7257 & 99.45 & 0.7128 \\
\hline
\end{tabular}


Table 2 Comparison of experimental and calculated $q_{e}$ values at different current densities for first- and second-order adsorption kinetics of lead with concentration of $2 \mathrm{mg} / \mathrm{L}$ at $303 \mathrm{~K}$

\begin{tabular}{|c|c|c|c|c|c|c|c|}
\hline \multirow{2}{*}{$\begin{array}{l}\text { Current density } \\
\left(\mathrm{A} / \mathrm{dm}^{2}\right)\end{array}$} & \multirow[t]{2}{*}{$q_{e}(\exp )$} & \multicolumn{3}{|c|}{ First-order adsorption } & \multicolumn{3}{|c|}{ Second-order adsorption } \\
\hline & & $q_{e}(\mathrm{Cal})$ & $k_{1} \times 10^{4}(\mathrm{~min} / \mathrm{mg})$ & $R^{2}$ & $q_{e}(\mathrm{cal})$ & $k_{2} \times 10^{4}(\mathrm{~min} / \mathrm{mg})$ & $R^{2}$ \\
\hline 0.2 & 1.938 & 0.94 & -0.0029 & 0.4875 & 1.930 & 0.0297 & 0.9958 \\
\hline 0.4 & 1.947 & 1.12 & -0.0033 & 0.5725 & 1.943 & 0.0323 & 0.9979 \\
\hline 0.6 & 1.949 & 1.41 & -0.0038 & 0.6883 & 1.936 & 0.0362 & 0.9933 \\
\hline 0.8 & 1.986 & 1.52 & -0.0042 & 0.7653 & 1.984 & 0.0399 & 0.9989 \\
\hline
\end{tabular}

density on the lead removal, a series of experiments were carried out using solutions containing $2 \mathrm{mg} / \mathrm{L}$ of lead, at a $\mathrm{pH} 7.0$, with current density being varied from 0.2 to $0.8 \mathrm{~A} / \mathrm{dm}^{2}$. Figure S2 shows the plot between amounts of lead adsorbed with respect to time at different current densities. From the figure, it was clear that the uptake of lead $(\mathrm{mg} / \mathrm{g})$ increased with increasing the current density and remained nearly constant after equilibrium time. The equilibrium time was found to be $25 \mathrm{~min}$ for all concentrations studied. After $25 \mathrm{~min}$, the amount of lead adsorbed $\left(\mathrm{q}_{\mathrm{e}}\right)$ increased from 1.115 to $1.986 \mathrm{mg} / \mathrm{g}$ as the current density increased from 0.2 to $0.8 \mathrm{mg} / \mathrm{L}$. The figure also shows that the adsorption is rapid in the initial stages and remains almost constant with the progress of the adsorption. The plots are single, smooth and continuous curves leading to saturation, suggesting the possible monolayer coverage of lead on the surface of the adsorbent (Jiang et al. 2002; Vasudevan et al. 2008; Malkoc and Nuhoglu 2007).

\section{Kinetic modeling}

In the present investigation, two kinetic models, namely first- and second-order models, were tested with the lead concentration of $2 \mathrm{mg} / \mathrm{L}$ at various current densities from 0.2 to $0.8 \mathrm{~A} / \mathrm{dm}^{2}$.

\section{First-order Lagergren model}

The experimental data were analyzed initially with firstorder Lagergren model (Sing et al. 2006). The plot of log $\left(q_{e}-q_{t}\right)$ versus $t$ should give the linear relationship, from which $k_{1}$ and $q_{e}$ can be determined by the slope and intercept, respectively, from Eq. (2). The computed results are given in Table 2. The results show that the theoretical $q_{e}$ (cal) value does not agree to the experimental $q_{e}$ (exp) values at all current densities studied with poor correlation coefficient. So, further the experimental data were fitted with second-order Lagergren model.

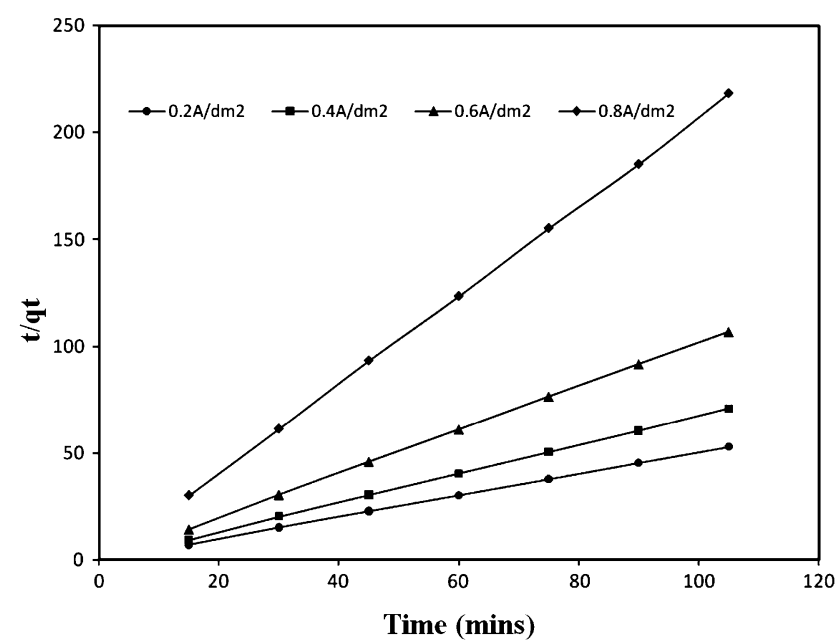

Fig. 1 Second-order kinetic model plot of different current densities for the adsorption of lead. Conditions-temperature $303 \mathrm{~K}$; $\mathrm{pH}$ of the electrolyte 7

Second-order Lagergren model

The kinetic data were fitted to the second-order Lagergren model (Mckay and Ys 1999) using Eq. (5). The equilibrium adsorption capacity, $\mathrm{q}_{\mathrm{e}}(\mathrm{cal})$ and $\mathrm{k}_{2}$ were determined from the slope and intercept of plot of $t / q_{t}$ versus $t$ (Fig. 1) and are given in Table 2. The plots were found to be linear with good correlation coefficients. The theoretical $q_{e}(\mathrm{cal})$ values agree well to the experimental $q_{e}(\exp )$ values at all current densities studied. This implies that the second-order model is in good agreement with experimental data and can be used to favorably explain the lead adsorption on $\operatorname{Mg}(\mathrm{OH})_{2}$.

Table 2 depicts the computed results obtained from firstand second-order models. From the results, it is observed that the correlation coefficients for the first-order kinetic model were relatively lower than those obtained for the second-order kinetic model for the different current densities. These results indicate that the second-order kinetic 
Table 3 Constant parameters and correlation coefficient for different adsorption isotherm models for lead adsorption at $0.5-2.0 \mathrm{mg} / \mathrm{L}$ at various current densities of $0.2-0.8 \mathrm{~A} / \mathrm{dm}^{2}$

\begin{tabular}{llllll}
\hline Isotherm & Parameters & \multicolumn{4}{l}{ Current density $\left(\mathrm{A} / \mathrm{dm}^{2}\right)$} \\
\cline { 3 - 6 } & & 0.2 & 0.4 & 0.6 & 0.8 \\
\hline Freundlich & $k_{f}(\mathrm{mg} / \mathrm{g})$ & 1.2012 & 1.5352 & 1.8735 & 2.0155 \\
& $n(\mathrm{~L} / \mathrm{mg})$ & 2.0026 & 2.0057 & 2.0096 & 2.0128 \\
& $R^{2}$ & 0.98755 & 0.9862 & 0.9843 & 0.9837 \\
Langmuir & $q_{m}(\mathrm{mg} / \mathrm{g})$ & 1.2281 & 1.7364 & 2.0247 & 2.3348 \\
& $b(\mathrm{~L} / \mathrm{mg})$ & 6.7540 & 5.1483 & 4.5278 & 3.9434 \\
& $R^{2}$ & 0.9992 & 0.9989 & 0.9981 & 0.9992 \\
& $R_{L}$ & 0.0689 & 0.0885 & 0.0994 & 0.1125 \\
\hline
\end{tabular}

model can be applied suitably to predict the lead adsorption process onto magnesium hydroxides.

Isotherm modeling

\section{Freundlich isotherm}

In testing the isotherm, the lead concentration used was $0.5-2.0 \mathrm{mg} / \mathrm{L}$ with various current densities from 0.2 to $0.8 \mathrm{~A} / \mathrm{dm}^{2}$ and at an initial $\mathrm{pH} 7$. The adsorption data are plotted as $\log q_{e}$ versus $\log C_{e}$ by Eq. (6) should result in a straight line with slope $\mathrm{n}$ and intercept $k_{f}$ (Freundlich 1906). The intercept and the slope are indicators of adsorption capacity and adsorption intensity, respectively. The value of $\mathrm{n}$ falling in the range of 1-10 indicates favorable sorption. $k_{f}$ and $n$ values are listed in Table 3 for each concentration and current density. It has been reported that values of $n$ lying between 0 and 10 indicate favorable adsorption. From the analysis of the results, it is found that the Freundlich plots fit satisfactorily with the experimental data obtained in the present study.

\section{Langmuir isotherm}

Langmuir isotherm (Langmuir 1918) was tested from Eq. (7). The plots of $1 / q_{e}$ as a function of $1 / C_{e}$ for the adsorption of lead on $\operatorname{Mg}(\mathrm{OH})_{2}$ are shown in Fig. 2. The plots were found linear with good correlation coefficients $(>0.99)$ indicating the applicability of Langmuir model in the present study. The values of monolayer capacity $\left(q_{m}\right)$ and Langmuir constant (b) are given in Table 3. The values of $q_{m}$ calculated by the Langmuir isotherm were all close to experimental values at given experimental conditions. These facts suggest that lead is

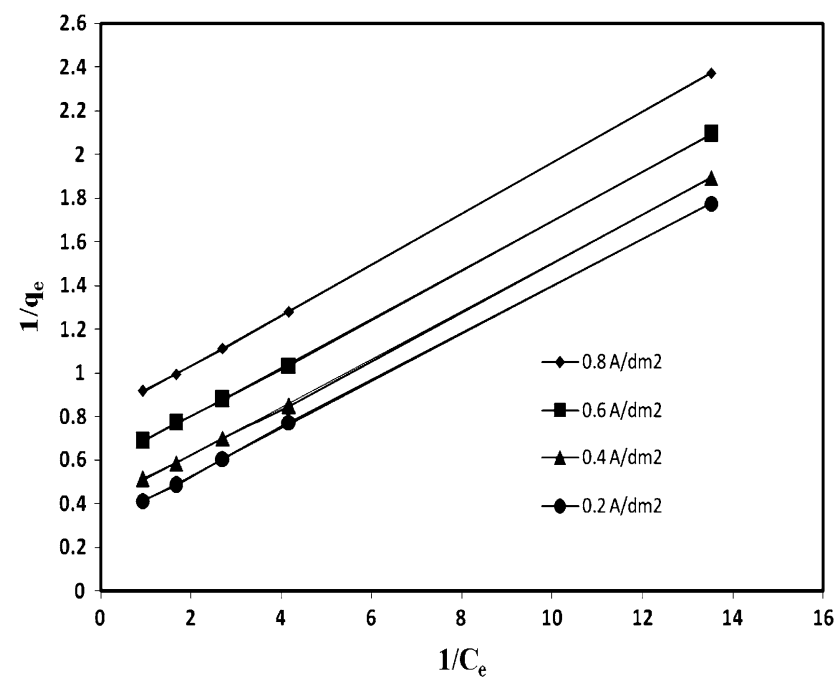

Fig. 2 Langmuir plot $\left(1 / \mathrm{q}_{\mathrm{e}}\right.$ vs. $\left.1 / \mathrm{C}_{\mathrm{e}}\right)$ for adsorption of lead. Conditions $-\mathrm{pH}$ of the electrolyte 7.0; current density $0.2-0.8 \mathrm{~A} / \mathrm{dm}^{2}$; temperature $303 \mathrm{~K}$; and concentration $2.0 \mathrm{mg} / \mathrm{L}$

adsorbed in the form of monolayer coverage on the surface of the adsorbent.

The applicability of the two isotherm equations was compared using the correlation coefficient $\left(R^{2}\right)$. The correlation coefficient values of Freundlich and Langmuir isotherm models are presented in Table 3 . The values of correlation coefficient $\left(R^{2}\right)$ are found to be $>0.9$ for both isotherms. However, based on the $R^{2}$ values, the Langmuir isotherm model provided a better fit compared to Freundlich isotherm model. This suggests that the adsorption of lead on magnesium hydroxides is apparent with monolayer coverage of adsorbed molecules. The dimensionless constant $R_{\mathrm{L}}$ were calculated from Eq. (8). The $R_{\mathrm{L}}$ values were found to be between 0 and 1 for all the concentration of lead studied.

\section{Thermodynamic parameters}

Figure 3 shows that the rate constants vary with temperature according to Eq. (10). The activation energy ($21.437 \mathrm{~kJ} / \mathrm{mol}$ ) is calculated from slope of the fitted equation. The free energy change is obtained from Eq. (11). The $K_{\mathrm{c}}$ and $\Delta G$ values are presented in Table 4 . From the table, it is found that the negative value of $\Delta G$ indicates the spontaneous nature of adsorption. The enthalpy change $(\Delta H=22.577 \mathrm{~kJ} / \mathrm{mol})$ and entropy change $(\Delta S=74.2032 \mathrm{k} \mathrm{J} / \mathrm{mol} \mathrm{K})$ were obtained from the slope and intercept of the van't Hoff linear plots of $\operatorname{lnk}_{\mathrm{c}}$ versus $1 / T$ (Figure S3) Eq. (12). Positive value of enthalpy change $(\Delta H)$ indicates that the adsorption 
process is endothermic in nature, and the negative value of change in internal energy $(\Delta G)$ shows the spontaneous adsorption of lead on the adsorbent (Yang and Al-Duri 2001). Positive values of entropy change show the increased randomness of the solution interface during the adsorption of lead on the adsorbent (Table 4). The enhancement of adsorption capacity of magnesium hydroxide at higher temperatures may be attributed to the enlargement of pore size and/or activation of the adsorbent surface (Vasudevan et al. 2010). Using Lagergren rate equation, second-order rate constants and correlation coefficient were calculated for different temperatures (303-333 K). The calculated ' $q_{e}$ ' values obtained from the second-order kinetics agree with the experimental ' $q_{e}$ '

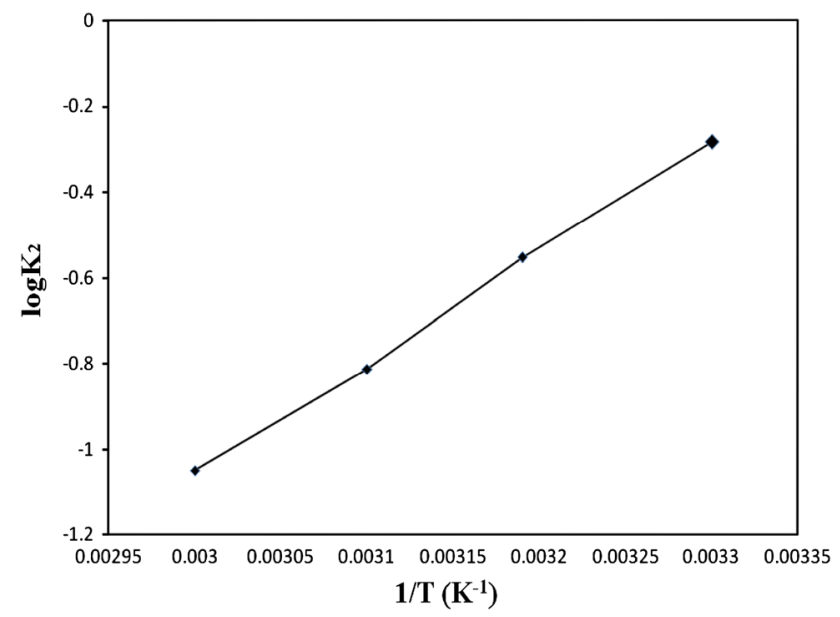

Fig. 3 Plot of $\log \mathrm{k}_{2}$ and $1 / \mathrm{T}$. Conditions- $\mathrm{pH}$ of the electrolyte 7.0; current density $0.8 \mathrm{~A} / \mathrm{dm}^{2}$; and concentration $2 \mathrm{mg} / \mathrm{L}$

Table 4 Thermodynamics parameters for adsorption of lead

\begin{tabular}{lllll}
\hline $\begin{array}{l}\text { Temperature } \\
(\mathrm{K})\end{array}$ & $K_{\mathrm{c}}$ & $\begin{array}{l}\Delta G^{\circ}(\mathrm{J} / \\
\mathrm{mol})\end{array}$ & $\begin{array}{l}\Delta H^{\circ}(\mathrm{kJ} / \\
\mathrm{mol})\end{array}$ & $\begin{array}{l}\Delta S^{\circ}(\mathrm{J} / \\
\mathrm{mol} \mathrm{K})\end{array}$ \\
\hline 313 & 0.2578 & -670.86 & & \\
323 & 0.5410 & $-1,452.81$ & 22.577 & 74.2032 \\
333 & 0.7734 & $-2,141.20$ & & \\
\hline
\end{tabular}

values better than the first-order kinetics model, indicating adsorption following second-order kinetics. Table 5 depicts the computed results obtained from first- and second-order kinetic models.

Effect of competing ions

\section{Carbonate}

Effect of carbonate on lead removal was evaluated by increasing the carbonate concentration from 0 to $250 \mathrm{mg} / \mathrm{L}$ in the electrolyte. The removal efficiencies are 99.3, 95.3, $72.8,50.7,38$ and $19 \%$ for the carbonate concentration of $0,2,5,65,150$ and $250 \mathrm{mg} / \mathrm{L}$, respectively. From the results, it is found that the removal efficiency of the lead is not much affected by the presence of carbonate below $2 \mathrm{mg} / \mathrm{L}$. Significant reduction in removal efficiency observed above $2 \mathrm{mg} / \mathrm{L}$ of carbonate concentration is due to the passivation of anode, resulting the hindering of the dissolution process of anode (Kabdasl et al. 2009).

\section{Phosphate}

The concentration of phosphate ion was increased from 0 to $50 \mathrm{mg} / \mathrm{L}$, the contaminant range of phosphate in the ground water. The removal efficiency for lead was 99.3, $96.3,64.7,41.5$ and $36.2 \%$ for $0,2,5,25$ and $50 \mathrm{mg} / \mathrm{L}$ of phosphate ion, respectively. A negligible change in removal efficiency of lead below $2 \mathrm{mg} / \mathrm{L}$ of phosphate in the water was observed. At higher concentrations (at and above $2 \mathrm{mg} / \mathrm{L}$ ) of phosphate, the removal efficiency decreases drastically. This is due to the preferential adsorption of phosphate over lead as the concentration of phosphate increases.

\section{Silicate}

From the results, it is found that no significant change in lead removal was observed when the silicate concentration

Table 5 Comparison between the experimental and calculated $q_{e}$ values for the lead concentration of $2 \mathrm{mg} / \mathrm{L}$ with $0.8 \mathrm{~A} / \mathrm{dm}^{2}$ in first- and second-order adsorption kinetics

\begin{tabular}{|c|c|c|c|c|c|c|c|}
\hline \multirow[t]{2}{*}{ Temperature $\left({ }^{\circ} \mathrm{K}\right)$} & \multirow[t]{2}{*}{$q_{e}(\exp )$} & \multicolumn{3}{|c|}{ First-order adsorption } & \multicolumn{3}{|c|}{ Second-order adsorption } \\
\hline & & $q_{e}(\mathrm{Cal})$ & $k_{1} \times 10^{4}(\mathrm{~min} / \mathrm{mg})$ & $R^{2}$ & $q_{e}(\mathrm{Cal})$ & $k_{2} \times 10^{4}(\mathrm{~min} / \mathrm{mg})$ & $R^{2}$ \\
\hline 303 & 1.986 & 1.52 & -0.0042 & 0.7653 & 1.9840 & 0.0399 & 0.9989 \\
\hline 313 & 1.988 & 1.78 & -0.0047 & 0.7124 & 1.9860 & 0.0402 & 0.9991 \\
\hline 323 & 1.991 & 1.97 & -0.0053 & 0.6845 & 1.990 & 0.0418 & 0.9994 \\
\hline 333 & 1.993 & 1.99 & -0.0067 & 0.6325 & 1.994 & 0.0437 & 0.9997 \\
\hline
\end{tabular}


Table 6 Effect of addition of carbonate, phosphate, silicate and arsenic in the electrolyte for the removal of lead from water

\begin{tabular}{lll}
\hline Concentration $\left(\mathrm{mg} \mathrm{L}^{-1}\right)$ & Voltage $(\mathrm{V})$ & Removal efficiency $(\%)$ \\
\hline Carbonate & & \\
Nil & 1.5 & 99.3 \\
2.0 & 1.5 & 95.3 \\
5.0 & 1.6 & 72.8 \\
65 & 2.1 & 50.7 \\
150 & 2.3 & 38.0 \\
250 & 2.6 & 19.0 \\
Phosphate & & \\
Nil & 1.5 & 99.3 \\
2.0 & 1.6 & 96.3 \\
5.0 & 1.6 & 64.7 \\
25 & 1.9 & 41.5 \\
50 & 2.3 & 36.2 \\
Silicate & & \\
Nil & & 99.3 \\
2.0 & 1.6 & 87.2 \\
5.0 & 1.7 & 82.4 \\
10 & 1.7 & 59.6 \\
15 & 2.1 & 51.8 \\
Arsenic & 2.3 & 99.3 \\
Nil & & 54.6 \\
0.2 & 1.6 & \\
0.5 & 1.6 & \\
2.0 & 2.1 & \\
5.0 & & \\
\hline & & \\
\hline
\end{tabular}

was increased from 0 to $2 \mathrm{mg} / \mathrm{L}$. The respective efficiencies for $0,2,5,10$ and $15 \mathrm{mg} / \mathrm{L}$ of silicate are 99.3, 87.2, $82.4,59.6$ and $51.8 \%$. In addition to preferential adsorption, silicate can interact with magnesium hydroxide to form soluble and highly dispersed colloids that are not removed by normal filtration.

\section{Arsenic}

The concentration of arsenic was increased from 0 to $5 \mathrm{mg}$ / L. From the results, it is found that the removal efficiency of lead was decreased by increasing the concentration of arsenic. The removal efficiencies are 99.3, 95.7, 83.5, 73.6 and $54.6 \%$ for $0,0.2,0.5,2.5$ and $5.0 \mathrm{mg} / \mathrm{L}$ of arsenic, respectively. This is due to the preferential adsorption of arsenic over lead as the concentration of arsenic increases. So, when arsenic ions are present in the water to be treated,

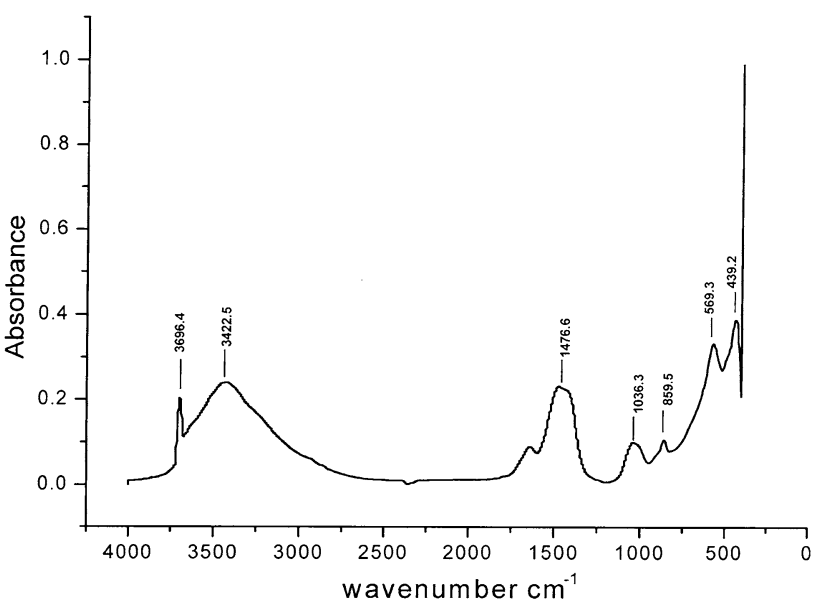

Fig. 4 FTIR spectrum of lead-adsorbed magnesium hydroxide

arsenic ions compete greatly with lead ions for the binding sites.

The comparative results on the effect of competing ions for the removal of lead are given in Table 6 .

Surface morphology

Characterization of the cathode surface

To investigate the possibility of direct deposition of lead on the cathode surface, the EDAX analysis was carried out on the cathode surface. The results showed that the amount of deposited lead on cathode surface is very low. The reason for this phenomenon may be that the hydrogen evolution from aqueous solutions will compete with metal deposition on the cathode surface. Hence, the direct cathodic deposition has insignificant effect on the removal of lead ions from aqueous solution.

\section{Characterization of the anode surface}

A SEM image of magnesium electrode after electrocoagulation of lead electrolyte was obtained (Figure S4). The electrode surface is found to be rough, with a number of dents. These dents are formed around the nucleus of the active sites where the electrode dissolution results in the production of magnesium hydroxides. The formation of a large number of dents may be attributed to the anode material consumption at active sites due to the generation of oxygen at its surface. The elemental constituent of leadadsorbed magnesium hydroxide is shown in Figure S5. It shows that the presence of $\mathrm{Pb}, \mathrm{Mg}$ and $\mathrm{O}$ appears in the spectrum. EDAX analysis provides direct evidence that lead is adsorbed on magnesium hydroxide. 
Material characterization

\section{FTIR and XRD studies}

Figure 4 presents the FT-IR spectrum of lead-magnesium hydroxide. The sharp and strong peak at 3,422.6/ $\mathrm{cm}$ is due to the $(\mathrm{O}-\mathrm{H})$ stretching vibration in the $\mathrm{Mg}(\mathrm{OH})_{2}$ structures. The $1,476.6 / \mathrm{cm}$ peak indicates the bent vibration of $\mathrm{H}-\mathrm{O}-\mathrm{H}$. Absorption band at $3,696.4 / \mathrm{cm}$ implies the transformation from free protons into a proton conductive state in brucite. The strong peak at $439.2 / \mathrm{cm}$ is assigned to the $\mathrm{Mg}-\mathrm{O}$ stretching vibration (Golder et al. 2006; Vasudevan et al. 2010). The spectrum data are in good agreement with the reported data (Golder et al. 2006). $\mathrm{Mg}-\mathrm{Pb}$ is observed in $-\mathrm{OH}$ stretching region. The Figure S6 shows the X-ray diffraction of lead-adsorbed magnesium hydroxide. From the figure, it is found that electrocoagulation byproduct showed the well crystalline phase ( $\mathrm{Li}$ et al. 2009) of magnesium hydroxide.

\section{Conclusion}

Based on the experimental results, it is concluded that the electrocoagulation is a promising technology for the removal of heavy metals such as lead from drinking water. The optimal removal efficiency of $99.3 \%$ was achieved at a current density of $0.8 \mathrm{~A} / \mathrm{dm}^{2}$ and at $\mathrm{pH} 7.0$ using magnesium as anode and stainless steel as cathode. The first- and second-order models were applied to identify the kinetics of lead adsorption onto magnesium hydroxides. The kinetic results showed that the lead adsorption on magnesium hydroxides was best described using the second-order kinetic model at various current densities studied. The electrocoagulation process was modeled using adsorption isotherm models viz., Langmuir and Freundlich. The lead adsorption was best fitted by the Langmuir adsorption isotherm, and the results were in good agreement with the experimental data. The thermodynamic parameters such as $\Delta G, \Delta H$ and $\Delta S$ were determined. Their values indicated that the adsorption process was favorable, spontaneous and endothermic in nature. As the temperature increased from 303 to $343 \mathrm{~K}$, the positive value of $\Delta H$ confirmed that the process was endothermic. The positive value of $\Delta S$ suggested the increased randomness of the lead adsorption from the water containing lead onto magnesium hydroxides. From the surface characterization studies, it is confirmed that the magnesium hydroxide generated in the cell adsorbed lead present in the water than direct cathodic deposition.
Acknowledgments The authors wish to express their gratitude to the Director, Central Electrochemical Research Institute, Karaikudi, to publish this paper.

\section{References}

Argun ME, Dursun S, Özdemir C, Karatas M (2007) Heavy metal adsorption by modified oak sawdust: thermodynamics and kinetics. J Hazard Mater 141:77-85

Butler E, Hung YT, Yu-Li Yeh R, Al Ahmad MS (2011) Electrocoagulation in wastewater treatment. Water 3:495-525

Freundlich HMF (1906) Über die Adsorption in Lösungen. Z Phys Chem 57A:385-470

Golder AK, Samantha AN, Ray S (2006) Removal of phosphate from aqueous solutions using calcinated metal hydroxides sludge waste generated from electrocoagulation. Sep Purif Technol 52:102-109

Gupta VK, Ali I (2004) Removal of lead and chromium from wastewater using bagasse fly ash- a sugar industry waste. J Colloid Interf Sci 271:321-328

Gupta VK, Sharma S (2002) Removal of cadmium and zinc from aqueous solution using red mud. Environ Sci Technol 36:3612-3617

Heil DM, Samani Z, Hanson AT, Rudd B (1999) Remediation of lead contaminated soils by EDTA. I. Batch and column studies. Water Air Soil Pollut 13:77-95

Inglezakis VJ, Stylianou MA, Gkantzou D, Loizidou MD (2007) Removal of $\mathrm{Pb}(\mathrm{II})$ from aqueous solutions by using clinoptilolite and bentonite as adsorbents. Desalination 210:248-256

Jiang JQN, Graham C, Andre G, Kelsall H, Brandon N (2002) Laboratory study on electro-coagulation-flotation for water treatment. Water Res 36:4064-4078

Kabdasl I, Vardar B, Arslan-Alaton I, Tunay O (2009) Effect of auxilaries on colour and COD removal from simulated reactive dye bath effluent by electrocoagulation. Chem Eng J 148:89-96

Kabdasl I, Arslan-Alaton I, Ölmez-Hanc T, Tünay O (2012) Electrocoagulation applications for industrial wastewaters: a critical review. Environ Technol Rev 1:2-45

Langmuir I (1918) The adsorption of gases on plane surface of glass, mica and platinum. Am Chem Soc 40:1361-1403

Li X, Ma GB, Liu YY (2009) Synthesis and characterization of magnesium hydroxide using a bubbling setup. Ind Eng Chem Res 48:763-768

Malkoc E, Nuhoglu Y (2007) Potential of tea factory waste for chromium (VI) removal from aqueous solutions: thermodynamic and kinetic studies. Sep Purif Technol 54:291-298

Matlock MM, Howerton BS, Atwood DA (2001) Irreversible precipitation of mercury and lead. J Hazard Mater 84:72-83

Mckay G, Ys Ho (1999) The sorption of lead(II) ions on peat. Water Res 33:578-584

Mohammad Y, Mollah A, Morkovsky P, Jewel A, Gomes G, Mehmet K, Parge J, Cock DL (2004) Fundamental, present and future perspectives of electro coagulation. J Hazard Mater 114:199-210

Mohan D, Chander S (2006) Removal and recovery of metal ions from acid mine drainage using lignite-a low cost sorbent. J Hazard Mater B137:1545-1553

Nurbas Nourbakhsh M, Kilicarslan S, Ilhan S, Ozdag H (2002) Biosorption of $\mathrm{Cr}^{+6}, \mathrm{~Pb}^{+2}$ and $\mathrm{Cu}^{+2}$ ions in industrial waste water on Bacillus sp. Chem Eng J 85:351-355

Oguz E (2004) Adsorption characteristics and kinetics of $\mathrm{Cr}(\mathrm{VI})$ on Thuja Orantalis. Colloids Surf 252:121-128 
Sing SP, Ma LQ, Hendry MJ (2006) Characterization of aqueous lead removal by phosphatic clay: equilibrium and Kinetic studies. J Hazard Mater B136:654-662

Vasudevan S, Sozhan G, Ravichandran S, Jeyaraj J, Sheela SM (2008) Studies on removal of phosphate from drinking water by electrocoagulation process. Ind Eng Chem Res 47:2018-2023

Vasudevan S, Lakshmi J, Packiyam M (2010) Electrocoagulation studies on removal of cadmium using magnesium electrode. J Appl Electrochem 40:2023-2032
WHO (World Health Organisation) (2009) Guidelines for drinking water quality, 3rd edn. WHO, Geneva

Yang XY, Al-Duri B (2001) Application of branched pore diffusion in the adsorption of reactive dyes on activated carbon. Chem Eng J 83:15-23 